\title{
Effect of Alkaline Pretreatment on the Properties of Nigerian Castor Seed (Ricinus communis L.) Oil and Biodiesel Produced Thereof
}

\author{
JOSHUA ISEOLUWA OREGE*1, ADEMOLA OLUWASEUN ADEYEMO', \\ ADEYINKA OLUBUNMI FASAKIN 1 , ODUNOLA BLESSING OMITOLA ${ }^{2}$, \\ USMAN ALI ${ }^{3}$ and EMMANUEL ILESANMI ADEYEYE ${ }^{1}$
}

\author{
'Department of Industrial Chemistry, Faculty of Science, Ekiti State University, \\ P M B 5363, Ado-Ekiti, Ekiti State, Nigeria. \\ ${ }^{2}$ Department of Chemistry, University of Ibadan, Ibadan, Oyo State, Nigeria. \\ ${ }^{3}$ Key Laboratory of Organic Solids, Institute of Chemistry Chinese Academy of Sciences, \\ Beijing, 100190, P. R. China. \\ ${ }^{3}$ Department of Chemistry, University of Agriculture, Faisalabad, 38040, Pakistan. \\ ${ }^{*}$ Corresponding author E-mail: joshua.orege @ eksu.edu.ng
}

http://dx.doi.org/10.13005/ojc/360114

(Received: October 31, 2019; Accepted: February 10, 2020)

\section{ABSTRACT}

This work focuses on production of biodiesel from natural and refined castor seed oil. Oil was extracted with normal-hexane solvent at $60^{\circ} \mathrm{C}$ using Soxhlet apparatus and pretreated by alkaline refining process before transesterification with methanolic potassium hydroxide solution as catalyst. The effect of alkaline refining on the oil characteristics and biodiesel quality parameters was investigated using standard test methods and fatty acid methyl ester was characterized using gas chromatography. Results revealed that alkaline refining had significant improvement on the oil and biodiesel characteristics. Yield of 43.9 and $46.2 \%$ were obtained for refined and unrefined castor oil respectively while biodiesel yield from refined and unrefined castor oil was 43.5 and $41.7 \%$ respectively. Ricinoleic acid (84.9\%) was prevalent in the oil with lignoceric $(0.03 \%)$ as the smallest. The conformity of refined castor oil biodiesel with EN 14214, ASTM and India biodiesel standards makes it viable economically in Nigeria.

Keywords: Castor oil, Alkaline refining, Methyl ester, Transesterification, Biodiesel.

\section{INTRODUCTION}

The growing interest in finding new, viable and sustainable alternatives to petro diesel, which is associated with rapid rise in price, projected decrease in supplies and environmental consequences has drawn the attention of researchers to renewable energy sources in recent years. One of the most prominent renewable energy sources are triglycerides from which biodiesels are produced.

This is an Open Access article licensed under a Creative Commons license: Attribution 4.0 International (CC- BY). Published by Oriental Scientific Publishing Company @ 2018 
Biodiesel is a free fatty mono alkyl ester derived majorly from vegetable oils and animal fat. It has excellent properties such as minimum exhaust emissions, enhanced biodegradability, minimum toxicity, enhanced lubricity ${ }^{1,2}$, eco-efficiency and sustainability, which makes it a better choice over petro diesel. In compression-ignition $(\mathrm{Cl})$ engines, in spite of its emission level of NOx, biodiesel combustion releases very low carbon monoxide, total hydrocarbon emissions and smoke $^{3}$ when compared with petro diesel combustion. This has been attributed to increased oxygen content, high heating value, less calorific value, viscosity and higher density of biodiesel ${ }^{4}$.

Different lipids, majority vegetable oils have long been used for biodiesel production worldwide ${ }^{5,6,7}$. In most of the developed countries, edible seeds such as soybean, rapeseed, sunflower, coconut, peanut, groundnut, palm, etc are the most common oil sources. Due to their competition with food, non-edible sources have been known to be most suitable for biodiesel production. Among the non-edible oil sources, castor seed oil has been identified as a sustainable biodiesel source due to its short growing period and high seed productivity. However, characteristics such as high viscosity, high acid value, free fatty $\mathrm{acid}^{8}$ and low volatility have limited its use. Studies have described few methods of pre-treating vegetable oil9,10,11,12,13,14 before subjection to transesterification for biodiesel production, but these pretreatment methods are associated with some drawbacks especially increased production $\operatorname{cost}^{15}$. In this work, we have made use of alkaline refining process for castor oil pretreatment before subjecting the oil to transesterification process. Both refined and unrefined castor seed oil (RCSO and UCSO) were converted to biodiesel and the effect of pretreatment on oil characteristics and biodiesel quality was studied. Castor seed oil biodiesel was characterized using gas chromatography. The oil and biodiesel quality parameters measured were compared with international specifications.

\section{MATERIALS AND METHODS}

\section{Materials}

Matured seeds of castor were obtained from a swampy area of Odo-Ado in Ado-Ekiti metropolis, Ekiti State, Southwestern Nigeria and authenticated at the Department of Plant Science and Biotechnology, Ekiti State University, Ado-Ekiti, Nigeria. Analytical grade chemicals and reagents were used. Standard test methods were used to conduct all analyses - pour point (ASTM D97), flash point (ASTM D93, K-16270 Pensky-Martens Closed Flash Tester, Kehler Instrument Company, USA), kinematic viscosity (ASTM D445), cetane number (ASTM D613), iodine value (ASTM D5554), relative density and heating value (ASTM D2015, 6200 Automatic Isoperibol Oxygen Bomb Calorimeter).

\section{Seeds Preparation}

The seeds were manually separated from dirt and air-dried for eight weeks during the dry harmattan season. The endosperms were removed manually and their moisture content was determined as described by the association of official analytical chemists ${ }^{16}$. The dry seeds were ground into powder using laboratory mortar and pestle.

\section{Oil Extraction and Pretreatment}

$44.6 \mathrm{~g}$ of the seed powder was weighed for extraction using n-hexane in a Soxhlet apparatus at $60^{\circ} \mathrm{C}$ for 6 hours. Solvent was removed in a rotavapour and oil yield $(46.2 \%)$ was obtained. The extracted oil was divided into two equal parts. The first fraction was pretreated by using alkaline refining process ${ }^{17}$ with some modifications: $10 \mathrm{~cm}^{3}$ of $18 \mathrm{M}$ $\mathrm{NaOH}$ was added to $10.30 \mathrm{~g}$ oil. The mixture was agitated for $30 \mathrm{~min}$, heated to $75^{\circ} \mathrm{C}$ and centrifuged. Refined oil yield was calculated. Both unrefined and refined castor oil were analyzed at the same time for their physicochemical characteristics according to AOAC standard test methods.

\section{Oil Conversion to Biodiesel}

Both the refined and unrefined oil were converted separately to biodiesel by base-catalyzed transesterification process using potassium methoxide. Potassium methoxide was prepared by dissolving a specific amount of $\mathrm{KOH}$ in the required amount of anhydrous methanol. The potassium methoxide mixture was gently introduced into a precise amount of oil in a conical flask, attached with a water condenser and placed on a magnetic stirrer hot plate between $60-64^{\circ} \mathrm{C}$ with continuous stirring for $8 \mathrm{~h}$ to ensure complete conversion. The mixture was gently transferred into a separating funnel and allowed to stand for $1 \mathrm{~h}$ to ensure complete separation into two distinct layers. The layer below was run off while the layer above containing the biodiesel was 
washed thrice with $20 \mathrm{~mL}$ distilled water at a time. The biodiesel was dried over anhydrous sodium sulphate and yield was determined before storing in sample bottles at room temperature. Castor oil biodiesel was analysed using GC and fuel properties were tested according to standards.

\section{GC Analysis}

Fatty acid was determined as methyl ester using Agilent 6890 Gas Chromatograph System equipped with HP INNOWAX (30 $\mathrm{m} \times 0.25 \mathrm{~mm} \times$ $0.25 \mu \mathrm{m})$ and Agilent ChemStation software. The setup conditions are carrier gas (nitrogen), split injection (split ratio: $20: 1)$, inlet temperature $\left(250^{\circ} \mathrm{C}\right.$ ), oven program (initial temperature at $60^{\circ} \mathrm{C}$, ramped at $12^{\circ} \mathrm{C} / \mathrm{min}$. for $20 \mathrm{~min}$. and then maintained for $2 \mathrm{~min}$. ramped again at $15^{\circ} \mathrm{C} / \mathrm{min}$. for $3 \mathrm{~min}$. and then maintained for $8 \mathrm{~min}$.), detector (FID), detector temperature $\left(320^{\circ} \mathrm{C}\right)$, hydrogen pressure $(22 \mathrm{psi})$, compressed air (35 psi). Though biodiesel is methyl ester, GC requires full conversion of oil to methyl ester, hence the need for further conversion. The methyl ester was prepared according to a standard procedure for $\mathrm{GC}$ analysis as follows: $20 \mathrm{mg}$ of the oil was mixed with $2 \mathrm{~cm}^{3}$ toluene. Then, $2 \mathrm{~cm}^{3}$ of $1.5 \%$ sulphuric acid in methanol was added to the mixture, stirred and incubated at $55^{\circ} \mathrm{C}$ overnight. $4 \mathrm{~cm}^{3}$ saturated solution of sodium chloride was added and vortexed. HPLC grade of hexane was added followed by addition of $3 \mathrm{~cm}^{3}$ of $2 \% \mathrm{NaHCO}^{3}$. The mixture was also vortexed and $180 \mu \mathrm{l}$ of the upper phase was taken for GC analysis.

\section{Statistical Analysis}

The experimental data generated were appraised using two forms of statistical analysis, which are descriptive and inferential. For the descriptive statistics, the followings were discussed: mean, standard deviation (SD), and coefficient of variation in per cent (CV\%). For inferential statistics, the followings were discussed: coefficient of correlation $\left(r_{x y}\right)$, coefficient of determination $\left(r_{x y}{ }^{2}\right)$, regression coefficient $\left(R_{x y}\right)$, coefficient of alienation or non-relationship $\left(C_{A}\right)$ and index of forecasting efficiency (IFE).

\section{RESULTS AND DISCUSSION}

\section{Physicochemical Characteristics of Oil}

Physicochemical characteristics of oil are vital parameters, which provide information on both chemical and physical properties. Fundamental oil characteristics which are vital for biodiesel production were evaluated. The effect of pretreatment on physicochemical characteristics of castor oil is shown in Table 1. Moisture content of the seed was determined to be $4.25 \%$. The oil yield obtained from castor seed was $46.2 \pm 0.04 \%$ and after the completion of refining process, the yield was found to have reduced by $4.98 \%$. Yields of both unrefined and refined castor oil investigated were greater than $31.99 \%$ obtained for Sudanese castor oil ${ }^{18}$ but lower than about $90 \%$ obtained for Jatropha ${ }^{19}$ and Tunisian castor oils ${ }^{20}$. Changes in oil yields could be as a result of their genotype and environmental conditions in the region of planting. It could also be as a result of the level of moisture in seed. Similar result of $43.4 \%$ was obtained for Jamaican castor bean oil ${ }^{21}$. The yield obtained from this investigation revealed that refined castor oil can serve as a potential biodiesel source.

Table 1: Physicochemical parameters of unrefined and refined castor seed (Ricinuscommunis L.) oil

\begin{tabular}{lcccc}
\hline \multirow{2}{*}{ Parameter } & \multicolumn{2}{c}{ Oil samples } & Differences & Percentage difference \\
& UCSO & RCSO & & \\
\hline \%Oil yield & & & \\
Acid value $(\mathrm{mg} \mathrm{KOH} / \mathrm{g})$ & $46.2 \pm 0.04$ & $43.9 \pm 0.07$ & 2.3 & 4.98 \\
\%Free fatty acid & $2.22 \pm 0.00$ & $1.26 \pm 0.00$ & 0.96 & 43.2 \\
Saponification value $(\mathrm{mg} \mathrm{KOH} / \mathrm{g})$ & $1.12 \pm 0.00$ & $0.63 \pm 0.00$ & 0.96 & 47.8 \\
Peroxide value $(\mathrm{mE} / \mathrm{kg})$ & $2.792 \pm 0.00$ & $1.63 \pm 0.00$ & 1.162 & 4.43 \\
\hline
\end{tabular}

UCSO is Unrefined castor seed oil; RCSO is Refined castor seed oil

aMean and Standard deviation of duplicate determination

Acid value measures the acidic component present in oil. Oil with free fatty acid level of less than one percent has been reported to reduce biodiesel yield. High acid value and \%free fatty acid were obtained for unrefined castor oil and this justified the purpose of alkaline refining. Due to the concentration of $\mathrm{NaOH}$ used to neutralize some of the FFA during the refining process, acid value 
and \%FFA of the castor oil were reduced by $56 \%$ (from 2.22 and $1.12 \mathrm{mg} \mathrm{KOH} / \mathrm{g}$ to 1.26 and $0.63 \mathrm{mg}$ $\mathrm{KOH} / \mathrm{g}$ respectively). These values were comparatively lower than acid value of 32.538 and $3.5 \mathrm{mgK} \mathrm{OH} / \mathrm{g}$ obtained for neem and jatropha curcas oil22.

Saponification values of the unrefined and refined castor oils were 172.85 and $165.19 \mathrm{mg} \mathrm{KOH} / \mathrm{g}$ respectively, indicating that the castor oil had higher molecular weight fatty acids. Results obtained for these oils were lower than $187.94 \mathrm{mg} / \mathrm{g}$ obtained for cotton seed oil ${ }^{23}$ and are also slightly below the AOCS specification for castor oil (176-184 mg KOH/g). This showed that the oil was considerably stable.

Peroxide value gives an indication of the extent of rancidity of oil. A high peroxide value increases the extent of oil rancidity. The peroxide value of the unrefined and refined castor oil, 2.79 and $1.63 \mathrm{mE} / \mathrm{kg}$ respectively, were found to be lower than $5.7 \mathrm{mE} / \mathrm{kg} 24$ and also lesser than 5.0 as recommended by ASTM 6751 and EN 14214. This indicates that rancidity will hardly occur on the oils and they will show good resistance to oxidation.

\section{Fuel Quality Parameters of Castor Oil Biodiesels}

The measured fuel quality parameters carried out in this study and the effect of pretreatment on these parameters are presented in Table 2. The parameters were measured in order to ascertain whether the refined methyl esters produced had adequate value as a biodiesel fuel.

Table 2: Fuel quality parameters of biodiesel produced from unrefined and refined castor seed oil and their comparison with EN 14214, ASTM D6751 and India biodiesel as well as ASTM D975 petro diesel specifications

\begin{tabular}{|c|c|c|c|c|c|c|c|c|c|}
\hline \multirow[t]{2}{*}{ Parameter } & \multirow[t]{2}{*}{ Method } & \multicolumn{2}{|c|}{ Oil samples } & \multirow[b]{2}{*}{ Difference } & \multirow[b]{2}{*}{ Percentage } & \multirow[t]{2}{*}{ EN 14214} & \multirow[t]{2}{*}{ ASTM D6751 } & \multirow[t]{2}{*}{ IBS } & \multirow[t]{2}{*}{ ASTM D975 } \\
\hline & & UCSOB & RCSOB & & & & & & \\
\hline Pour point $\left({ }^{\circ} \mathrm{C}\right)$ & ASTM D97 & -12.93 & -17.52 & -4.59 & 26.2 & -15 to -16 & - & - & - \\
\hline Flash point $\left({ }^{\circ} \mathrm{C}\right)$ & ASTM D93 & 98.25 & 89.12 & 9.13 & 9.29 & 101 (min.) & 130 (min.) & 120 (min.) & $60-80$ \\
\hline $\begin{array}{l}\text { Kinematic viscosity@ } \\
40^{\circ} \mathrm{C}\left(\mathrm{mm}^{2} / \mathrm{s}\right)\end{array}$ & ASTM D445 & 6.1 & 4.34 & 1.76 & 28.9 & $3.5-5.0$ & $1.9-6.0$ & $2.5-6.0$ & $1.9-4.1$ \\
\hline Heating value (MJ/kg) & ASTM D240 & 41.92 & 40.67 & 1.25 & 2.9 & - & - & - & - \\
\hline Cetane number & ASTM D613 & 51.4 & 62.80 & 11.4 & 18.2 & 51 (minimum) & 47 (minimum) & 51 (minimum) & - \\
\hline lodine value $\left(\mathrm{g} \mathrm{I}_{2} / 100 \mathrm{~g}\right)$ & AOCS 1997b & 92.65 & 86.40 & 6.25 & 6.75 & 120 (max) & - & - & - \\
\hline Relative density & - & 0.894 & 0.856 & 0.038 & 4.25 & - & - & - & - \\
\hline
\end{tabular}

UCSOB is unrefined castor seed oil biodiesel; RCSOB is Refined castor seed oil biodiesel; IBS is India Biodiesel specification \%Biodiesel yield from UCSO and RCSO is 41.70 and $43.50 \%$ respectively

Pour point measures the minimum temperature at which biodiesel will flow in a given condition. From our investigation, pour point of unrefined and refined castor oil biodiesel was obtained at $-12.9^{\circ} \mathrm{C}$ and -17.5 respectively. Both values were lesser than the climatic temperature achievable in the region of testing. It implied that unrefined castor oil biodiesel could be used in any cold country whose climatic temperature is $\geq-13^{\circ} \mathrm{C}$ while refined castor oil biodiesel could be used under a climatic temperature of about $\geq-17.5^{\circ} \mathrm{C}$.

Flash point is the lowest temperature at which biodiesel ignite in air. It measures the purity of biodiesel and determines whether biodiesel is safer for store, handle and transport. Biodiesel produced from unrefined castor oil recorded a flash point of $98.25^{\circ} \mathrm{C}$. After refining, the value dropped to $89.12^{\circ} \mathrm{C}$, which is higher than the ASTM D9751 specification of $60-80^{\circ} \mathrm{C}$ for petro diesel, indicating that the refined castor oil biodiesel will be safer to store, handle and transport than petro diesel. Flash point obtained for refined castor oil biodiesel was also below EN 14214 biodiesel standard of 101 minute.

One of the most important criteria for selecting feed stocks for biodiesel is kinematic viscosity. High viscosity results in fuel engine problems like carbon deposits ${ }^{25}$. Result obtained for unrefined castor oil biodiesel was $6.1 \mathrm{~mm}^{2} / \mathrm{s}$, which was slightly higher than ASTM D 6751, EN 14214 and India biodiesel specifications. After refining, the value reduced to $4.34 \mathrm{~mm}^{2} / \mathrm{s}$, which met ASTM, EN and India standards for pure biodiesel.

Heating value is a parameter that measures the quantity of heat released by combustion of a unit of biodiesel. It indicates biodiesel combustion 
efficiency. The heating value obtained for unrefined castor oil biodiesel (UCSOB) was $40.7 \mathrm{MJ} / \mathrm{kg}$ and after refining, it was raised to $41.9 \mathrm{MJ} / \mathrm{kg}$. This showed the effect of alkaline pretreatment on the combustion efficiency of the biodiesel. However, both values were slightly lower than $45.825 \mathrm{MJ} / \mathrm{kg}$ recommended for petro diese ${ }^{26}$. Decrease in the heating values limit biodiesel when compared with petro diesel as this will lead to reduction of power and torque as well as increase in fuel consumption rate re $^{27,28}$.

Cetane number is a parameter which indicates ignition efficiency of biodiesel in fuel engines. Low cetane number fuel gives rise to difficult starting and pollution. Biodiesel produced from unrefined castor oil had cetane number of 51.4 and after refining, the value increased to 62.8 . Both values met the recommended minimum for ASTM D675, EN and India biodiesel standards and this is an indication that the biodiesel produced could be auto-ignited in the diesel engine without any negative effect.

lodine value is determined as the $\mathrm{mg}$ of iodine absorbed per $100 \mathrm{~g}$ of fuel. It measures the degree of unsaturation present in fuel. High iodine value indicates high unsaturation. The higher the unsaturation, the lower the combustion quality and shelf life of biodiesel. lodine value of $92.65 \mathrm{mg} \mathrm{KOH} / \mathrm{g}$ was obtained for biodiesel from unrefined castor oil. After refining, the value reduced by $6.74 \%(86.40 \mathrm{mg}$ $\mathrm{KOH} / \mathrm{g}$ ), indicating a decrease in unsaturation. The lower unsaturation in the biodiesel produced from the refined oil may be due to removal of unsaturated FFAs during refining.

The relative densities-a parameter with implications for flow and haulage-of the biodiesel produced are within standard specifications $(0.860$ $-0.900)$. The values for biodiesel from unrefined and refined castor oil are 0.894 and 0.856 respectively.

\section{Fatty Acid Methyl Ester of Castor Oil}

Table 3 showed the fatty acid methyl ester of castor oil biodiesel investigated. Specific fuel quality parameters of biodiesel have been greatly influenced by different types and concentration of fatty acid ${ }^{1,2}$. According to $\mathrm{GC}$ analysis, twelve kinds of fatty acids in the esters were identified and quantified with the total unsaturated fatty acids consisting of about $95.9 \%$ of the total fatty acid. This is relatively lower than $97.6 \%$ reported for castor oil ${ }^{29}$. The castor oil (methyl ester) biodiesel had ricinoleic acid (84.86\%) as the major fatty acid. Similar result was recorded for castor oil biodiesel from Brazil ${ }^{30}$. The ricinoleic acid's dominance gives castor oil so many industrial applications notably as lubricant.

Table 3: Fatty acid methyl ester of castor seed oil

\begin{tabular}{lccccc}
\hline Fatty Acid & CAS Number & Formula & Structuref & Systematic name & Wt(\%) \\
\hline Caprylic & $124-07-2$ & $\mathrm{C}_{8} \mathrm{H}_{16} \mathrm{O}_{2}$ & $8: 0$ & Octanoic & 0.000000 \\
Capric & $334-48-5$ & $\mathrm{C}_{10} \mathrm{H}_{20} \mathrm{O}_{2}$ & $10: 0$ & Decanoic & 0.000000 \\
Lauric & $143-07-7$ & $\mathrm{C}_{12} \mathrm{H}_{24} \mathrm{O}_{2}$ & $12: 1$ & Dodecanoic & 0.000000 \\
Myristic & $544-63-8$ & $\mathrm{C}_{14} \mathrm{H}_{28} \mathrm{O}_{2}$ & $14: 0$ & Tetradecanoic & 0.096747 \\
Palmitic & $57-10-3$ & $\mathrm{C}_{16} \mathrm{H}_{32} \mathrm{O}_{2}$ & $16: 0$ & Hexadecanoic & 2.420577 \\
Palmitoleic & $373-49-9$ & $\mathrm{C}_{16} \mathrm{H}_{30} \mathrm{O}_{2}$ & $16: 1$ & cis-9-Hexadecenoic & 0.152333 \\
Margaric & $506-12-7$ & $\mathrm{C}_{17} \mathrm{H}_{34} \mathrm{O}_{2}$ & $17: 0$ & Heptadecanoic & 0.124042 \\
Stearic & $57-11-4$ & $\mathrm{C}_{18} \mathrm{H}_{36} \mathrm{O}_{2}$ & $18: 0$ & Octadecanoic & 1.429334 \\
Oleic & $112-80-1$ & $\mathrm{C}_{18} \mathrm{H}_{34} \mathrm{O}_{2}$ & $18: 1$ & cis-9-octadecenoic & 3.667484 \\
Linoleic & $60-33-3$ & $\mathrm{C}_{18} \mathrm{H}_{32} \mathrm{O}_{2}$ & $18: 2$ & cis-9-,cis-12-octadecedianioc & 6.624111 \\
Linolenic & $506-26-3$ & $\mathrm{C}_{18} \mathrm{H}_{30} \mathrm{O}_{2}$ & $18: 3$ & cis-6-,cis-9-,cis-12-octadecatrienoic & 0.423329 \\
Ricinoleic & $141-22-0$ & $\mathrm{C}_{18} \mathrm{H}_{34} \mathrm{O}_{3}$ & $18: 1 \mathrm{OH}$ & $12-$ hydroxy-9-cis-octadecenoic & 84.862856 \\
Arachidic & $506-30-9$ & $\mathrm{C}_{20} \mathrm{H}_{40} \mathrm{O}_{2}$ & $20: 0$ & Eicosanoic & 0.000000 \\
Arachidonic & $506-32-1$ & $\mathrm{C}_{20} \mathrm{H}_{32} \mathrm{O}_{2}$ & $20: 4$ & Cis-6-,cis-9-,cis-15-,Docosatetranoic & 0.000000 \\
Behenic & $112-85-6$ & $\mathrm{C}_{22} \mathrm{H}_{44} \mathrm{O}_{2}$ & $22: 0$ & Docosanoic & 0.043670 \\
Erucic & $112-86-7$ & $\mathrm{C}_{22} \mathrm{H}_{42} \mathrm{O}_{2}$ & $22: 1$ & cis-9-Docosenoic & 0.122960 \\
Lignoceric & $557-59-5$ & $\mathrm{C}_{24} \mathrm{H}_{48} \mathrm{O}_{2}$ & $24: 0$ & Tetracosanoic & 0.032557 \\
\hline Lx:y mean & $5 x$ & &
\end{tabular}

${ }^{f} x x: y$ means $x x$ carbons in the fatty acids with $y$ double bonds.

$4.15 \%$ of saturated fatty acids

$95.85 \%$ of unsaturated fatty acids 


\section{Results of the Statistical Analyses}

The statistical results (Tables 4 and 5) were generated from the physicochemical parameters of unrefined and refined castor seed oil (UCSO and RCSO) (Table 1) and the fuel parameters of biodiesel derived from unrefined and refined castor seed oil (UCSOB and RCSOB) (Table 2) respectively. These analyses were carried out to give information on the significance of alkaline refining of the castor seed oil. The $r_{x y}$ values were subjected to Table comparison at critical level of $r_{=0.05}$ at df of $n-2(5-2=3)$ for Table 4 and df of $n-2$ $(7-2=5)$ for Table 5. In each case, $r_{x y \text { calculated }}>r_{x y}$ Table, hence values of $r_{x y}$ in Tables 4 and 5 were significantly different as the case may be. The $r_{x y}$ values were subjected to Table comparison at critical level of $r_{=0.05}$ at df of $n-2(5-2=3)$ for Table 4 and df of $n-2(7-2=5)$ for Table 5 . In each case, $r_{x y \text { calculated }}>r_{x y \text { Table }}$, hence values of $r_{x y}$ in Tables 4 and 5 were significantly different as the case may be.

Table 4 showed the statistical result of physicochemical parameters of both unrefined and refined castor seed oil samples studied. The correlation coefficient $\left(r_{x y}\right)$ was high and significant at a value of 0.9999. It is significant because $r_{x y(0.9999)}>r_{T(0.878)} \cdot r_{x y}{ }^{2}$ was also high at a value of 0.9999 . The regression coefficient $\left(R_{x y}\right)$ revealed that every one unit increase in UCSO give rise to an increase of 0.9602 in RCSO. Mean of UCSO (45.0) > mean of RCSO (42.5); also the standard deviation showed the value for UCSO (74.0) > RCSO (71.0). In the coefficient of variation percent (CV\%), the value in UCSO was 164 but it was 167 in RCSO. Since CV\% in UCSO < RCSO, then the various values in UCSO were more homogeneous than the values in RCSO. $\mathrm{C}_{\mathrm{A}}$ was low at $0.0037(0.4 \%)$ whereas IFE was high at $0.9963(99.6 \%)$. The $C_{A}$ is the value representing the error of prediction between two relationships whereas IFE is a reduction value in the error of prediction between two relationships. The higher the $\mathrm{C}_{\mathrm{A}}$, the lower the IFE and vice versa. In this Table 4, $\mathrm{C}_{\mathrm{A}(0.4 \%)} \ll$ IFE $(99.6 \%)$, hence prediction of relationship is easy.

In Table 5, the statistical results were generated from the statistical analysis of the fuel quality parameters of biodiesel produced from unrefined and refined castor seed oil as given in Table 2. As in Table 4, $r_{x y}$ was high (0.9865) and significant $\left(r_{x y(0.9865)}>r_{T(0.754)}\right)$ at $n-2(d f)(7-2=5)$ with a critical level of $r={ }_{0.05}$. The $r_{x y}{ }^{2}$ was also high $\left(r_{x y}{ }^{2}=0.9732\right)$.
$\mathrm{R}_{\mathrm{xy}}$ revealed that every one unit increase in UCSO gives rise to an increase of 0.9443 in RCSO. It is however noted that $r_{x y}, r_{x y}{ }^{2}$ and $R_{x y}$ were each lesser than the corresponding values in Table 4. Mean, SD and $\mathrm{CV} \%$ were in the samples within each parameter, that is: mean (44.0 - 42.4); SD (39.5-37.8) and CV\% $\left(89.6\right.$ - 89.1). The $\mathrm{C}_{\mathrm{A}}(0.1637,16.4 \%)$ was higher than the $\mathrm{C}_{\mathrm{A}}$ in Table 4 whereas the IFE $(0.8363,83.6 \%)$ which is lower than the value in Table 4. However, since $\mathrm{C}_{\mathrm{A}(16.4 \%)}<\mathrm{IFE}{ }_{(83.6 \%)}$, then the error of prediction of relationship is low. Hence, UCSO can be substituted with RCSO and vice versa.

\begin{tabular}{|c|c|c|c|}
\hline Statistics & UCSO & & RCSO \\
\hline Correlation coefficient $\left(r_{x y}\right)$ & & 0.9999 & \\
\hline Coefficient of determination $\left(r_{x y}{ }^{2}\right)$ & & 0.9999 & \\
\hline Regression coefficient $\left(R_{x y}\right)$ & & 0.9602 & \\
\hline Mean & 45.0 & & 42.5 \\
\hline Standard deviation & 74.0 & & 71.0 \\
\hline Correlation of variation (CV\%) & 164 & & 167 \\
\hline coefficient of alienation $\left(C_{A}\right)$ & & 0.0037 & \\
\hline index of forecasting efficiency (IFE) & & 0.9963 & \\
\hline Remark & & * & \\
\hline
\end{tabular}

${ }^{*}=$ results were significantly different at $n=2(d f)_{(5-2=3)}$ and $r_{=0.05}$; $\left[\mathrm{r}_{\mathrm{T}=0.878}\right.$ (critical value)]

Table 5: Statistical analysis for fuel quality parameters of biodiesel produced from unrefined and refined castor seed oil

\begin{tabular}{lccc}
\hline Statistics & UCSO & RCSO \\
\hline correlation coefficient $\left(r_{x y}\right)$ & & 0.9865 & \\
Coefficient of determination $\left(r_{\mathrm{xy}}{ }^{2}\right)$ & & 0.9732 & \\
Regression coefficient $\left(\mathrm{R}_{\mathrm{xy}}\right)$ & & 0.9443 & \\
Mean & 44.0 & & 42.4 \\
Standard deviation & 39.5 & & 37.8 \\
Correlation of variation $(\mathrm{CV} \%)$ & 89.6 & & 89.1 \\
Coefficient of alienation $\left(\mathrm{C}_{\mathrm{A}}\right)$ & & 0.1637 & \\
Index of foresting efficiency (IFE) & & 0.8363 & \\
Remark & & $*$ & \\
\hline
\end{tabular}

${ }^{*}=$ results were significantly different at $n=2(\mathrm{df})_{(7-2=5)}$ and $r_{=0.05}$ $\left[\mathrm{r}_{\mathrm{T}=0.754}\right.$ (critical value)]

Comparison of Values Obtained for Fuel Quality Parameters in the present work with those reported in Literature from Different Countries

Table 6 showed a comparison of values obtained for some selected fuel quality parameters of the castor oil biodiesel studied with other values reported in literature from other countries. The vital 
parameters compared were pour points, flash points, kinematic viscosity @ $40^{\circ} \mathrm{C}$, heating values, cetane numbers, iodine values, relative densities and also percentage biodiesel yields.

Table 6: Comparison of values obtained for fuel quality parameters in this study with previous reports from some selected countries

\begin{tabular}{|c|c|c|c|c|c|c|c|c|c|c|}
\hline \multirow[t]{2}{*}{ Samples } & \multicolumn{10}{|c|}{ Parameter } \\
\hline & $\%$ Yield & $\begin{array}{c}\text { Pour } \\
\text { point }\left({ }^{\circ} \mathrm{C}\right)\end{array}$ & $\begin{array}{c}\text { Flash } \\
\text { point }\left({ }^{\circ} \mathrm{C}\right)\end{array}$ & $\begin{array}{c}\text { Kinematic } \\
\text { viscosity } \\
@ 40^{\circ} \mathrm{C} \\
\left(\mathrm{mm}^{2} / \mathrm{s}\right)\end{array}$ & $\begin{array}{l}\text { Heating } \\
\text { value } \\
(\mathrm{MJ} / \mathrm{kg})\end{array}$ & $\begin{array}{l}\text { Cetane } \\
\text { number }\end{array}$ & $\begin{array}{l}\text { lodine } \\
\text { value } \\
\text { (g/100g) }\end{array}$ & $\begin{array}{c}\text { Relative } \\
\text { density }\end{array}$ & Origin & References \\
\hline UCSOB & 41.6 & -12.93 & 98.12 & 5.10 & 41.92 & 51.40 & 92.65 & 0.894 & Nigeria & This study \\
\hline RCSOB & 43.52 & -17.52 & 89.25 & 4.34 & 40.67 & 62.80 & 86.40 & 0.856 & Nigeria & This study \\
\hline Refined COME Biodiesel & $88-92$ & - & - & 20.62 & - & - & - & 0.9 & Nepal & (31) \\
\hline COME Biodiesel & 95 & -30 & 194 & 15.40 & - & 43.7 & & - & Egypt & (32) \\
\hline Castor oil biodiesel & - & - & 120 & 13.75 & - & 50 & - & 0.9245 & Pakistan & (33) \\
\hline COME Biodiesel & - & - & 179 & - & 38.576 & - & - & 0.914 & Egypt & (34) \\
\hline COME Biodiesel & - & - & $131.2-135$ & $12.5-20$ & 40.5 & 57.7 & 86 & 0.92 & Ethiopia & (35) \\
\hline Castor biodiesel & $55-65$ & - & 130 & - & - & - & - & 0.921 & Malaysia & (36) \\
\hline Castor oil biodiesel & $80-82$ & -45 & 190.7 & 15.98 & 37.9 & - & - & 0.9268 & Colombia & (37) \\
\hline
\end{tabular}

Note: 1 centistoke $=1 \mathrm{~mm}^{2} / \mathrm{s}$; COME means Castor oil Methyl Ester; UCSOB is unrefined castor seed oil biodiesel; RCSOB is Refined castor seed oil biodiesel

\section{CONCLUSION}

This work has provided technical data on the effect of alkaline pretreatment on physicochemical properties of castor oil and biodiesel quality. Castor seed oil was refined by alkaline refining process and then trans-esterified using methanolic solution of potassium hydroxide as catalyst to produce refined castor oil (methyl ester) biodiesel. Alkaline refining process showed significant improvement on the biodiesel quality. Some measured biodiesel parameters met international standards. Our results recommended that refined castor oil would be a potential biodiesel feedstock, as pretreatment of the extracted oil helped to lower the acid value and viscosity of castor oil biodiesel. Castor oil plant is non-edible and renewable. It also has vast industrial applications. Therefore, it should be planted on a large scale as a renewable source of biodiesel feedstock.

\section{ACKNOWLEDGMENT}

This research did not receive any specific grant from funding agencies in the public, commercial, or not-for-profit sectors.

\section{Conflict of Interest}

The authors declare no conflict of interest regarding the publication of this article.

\section{REFERENCES}

1. Knothe, G.; Steidley, K. R.; Fuel., 2005, 84, 1059-1065.

2. Moser, B. R.; In vitro Cellularand Developmental Biology-Plant., 2009, 45, 229-266.

3. Chattopadhyay, S.; Sen, R.; Applied Energy, 2013, 105, 319-26.

4. Shrirame, H. Y.; Panwar, N. L.; Bamniya, B. R.; Low Carbon Economy., 2011, 2, 1-6. DOI: 10.4236/lce.2011.21001.

5. Mani, N.; Proceedings of International Conference on Sustainable Mobility, December, Kuala Lumpur, Malaysia., 2010, 1-18.

6. Ibeto, C. N.; Ofoefule, A. U.; Ezugwu, H. C.; Trends in Applied Sciences Research., 2011, 6,
537-553. DOI: 10.3923/tasr.2011.537.553.

7. Ayoola, A. A.; Hymore, K. F.; Omonhinmin, C. A.; Biotechnology., 2017, 16, 1-9. DOI: 10.3923/biotech.2017.1.9. 2003.

8. Salimon, J.; Mohd Noor, D. A.; Nazrizawati, A. T.; MohdFirdaus, M. Y.; Sain Malaysiana., 2010, 39(5), 761-764.

9. Turkay, S.; Civelekoglu, H.; Journal of American Oil Chemical Society., 1991, 68, 83-6.

10. Zappi, M.; Hernandez, R.; Sparks, D.; Horne, J.; Brough, M.; Arora, S. M.; Motsenbocker, W. D.; Mississippi Biomass Council, Jackson, MS., 2003, 71. 
11. Akpan, U. G.; Jimoh, A.; Mohammed, A. D.; Leonardo Journal of Sciences., 2006, 8, 43-52.

12. Sahoo, P.K.; Das, L. M.; Babu, M. K. G.; Naik, S. N.; Fuel., 2007, 86, 448-454.

13. Naik, M.; Meher, L. C.; Naik, S. N.; Das, L. M.; Biomass and Bioenergy., 2008, 32, 354-357. DOI: 10.1016/j.biombioe.2007.10.006.

14. Zhang, Y.; Lu, X. H.; Yu, Y. L.; Ji, J. B.; Study on the coupling process of catalytic esterification and extraction of high acid value waste oil with methanol. In International Conference on Biomass Energy Technologies, (Zhuang X, editor). Guangzhou, China., 2008.

15. Lotero, E.; Liu, Y.; Lopez, D. E.; Suwannakarn, K.; Bruce, D. A.; Goodwin, J. G. Jr.; Industrial and Engineering Chemistry Research., 2005, 44, 5353-5363.

16. AOAC. Official methods of analysis ( $2^{\text {nd }} \mathrm{ed}$.), Washington D. C. press., 1997, 56.

17. Azeez, A. M.; Fasakin, A. O.; Orege, J. I.; Green and Sustainable Chemistry., 2019, 9, 1-10. DOI: 10.4236/gsc.2019.91001.

18. Abdelaziz, A. I. M.; Elamin, I. H. M.; Gasmelseed, G. A.; Abdalla, B. K.; Journal of Chemical Engineering., 2014, 2(1),1-4.

19. Abdulkareem, A. S.; Jimoh, A.; Afolabi, A. S.; Odigure, J. O.; Patience D.; Energy Conservation. InTech. 2012, 171-196. Open access publisher. http://dx.doi.org/10.5772/ 51341.

20. Bouaziz, M.; Harebi, M.; Mahfoudhi, M.; Jebeur, H.; BouguerraNeji, S.; Archives of Petroleum and Environmental Biotechnology., APEB-118, 2017, 2(3), 1-7.

21. Gregory, C.R.; Smith, R.N.; Simpson, L. Castor bean production: The CARDI Experience, Castor Growers Workshop, Jamaica Castor Industry Association (JAMPRO Building) Kingston., 2017, 10, 10.

22. Aransiola, E.; Betiku, E.; Ikhuomoregbe, D.; Ojumu, T.; African Journal of Biotechnology., 2012, 11(22), 6178-6186.

23. Onukwuli, D. O.; Emembolu, L. N.; Ude, C. N.; Aliozo, S. O.; Menkiti, M. C.; Egyptian Journal of Petroleum., 2017, 26, 103-110.
24. Omohu, O. J.; Omale, A. C.; European Journal of Biophysics., 2017, 5(4), 62-65. DOI: 10.11648/j.ejb.20170504.11.

25. Ribeiro, A.; Castro, F.; Carvaiho, J.; Influence of free fatty acid content in biodiesel production on non-edible oils. In Wastes: Solutions, Treatments and Opportunities. $1^{\text {st }}$ International Conference, $12^{\text {th }}-14^{\text {th }}$ September., 2011.

26. Ong, H. C.; Silitonga, A. S.; Masjuki, H. H.; Mahlia, T. M. I.; Chong, W. T.; Boosroh, M. $\mathrm{H}$.; Energy Conversion and Management, 2013, 73, 245-255. DOI: 10.1016/j.enconman. 2013.04.011.

27. Mattarelli, E.; Rinaldini, C. A.; Savioli, T.; Energies., 2015, 8, 3047-3057.

28. Benavides, A.; Benjumea, P.; Pashova, V.; Diesel Dyna., 2017, 74, 141-150.

29. Conceicao, M. M.; Candeia, R. A.; Silva, F. C.; Bezerra, A. F.; Fernandes Jr.; V. J., Souza, A. G.; Renewable and Sustainable Energy Reviews., 2007, 11, 964-975.

30. Sanchez, N., Sanchez, R., Encinar, J. M., Gonzalez, J. F., Martinez, G.; Fuel., 2015, 147, 95-99. DOI: 10.1016/j.fuel.2015.01.062.

31. Nakarmi, A.; Joshi, S.; Nepal Journal of Science and Technology., 2014, 15(1), 45-52.

32. Keera, S. T.; El Sabagh, S. M.; Taman, A. R.; Egyptian Journal of Petroleum., 2018, 27, 979-984.

33. Chakrabarti, M. H.; Ali, M. ; NED University Journal of Research., 2009, 6(1), 10-19.

34. Soliman, M. S.; Mohamed, H. A.; Abdelhafez, A. O.; Nassibe, A. M.; International Research Journal of Engineering Science, Technology and Innovation., 2014, 3(2), 17-23. DOI: 10.14303/irjesti.2013.039.

35. Asmare, M.; Gabbiye, N.; American Journal of Energy Engineering., 2014, 2, 1-15.

36. Ismail, S.; Abu, S. A. ; Rezaur, R.; Sinin, H. ; ASEAN Journal on Science and Technology for Development., 2014, 31(1), 91-101.

37. Forero, C. L. B.; Renewable Energy and Power Quality Journal., 2005, 1(3), 59-62. DOI: 10.24084/repqj03.222. 